\title{
ANALISIS DETERMINAM KETIMPANGAN PENDAPATAN DI KABUPATEN MALUKU TENGGARA BARAT
}

\author{
Balthasar Malindar, \\ Sekolah Tinggi Ilmu Ekonomi Saumlaki, balthasar_malindar01@yahoo.com
}

\begin{abstract}
ABSTRAK
Tujuan penelitian ini adalah untuk menganalisis ketimpangan pendapatan di Kabupaten Maluku Tenggara Barat dengan menggunakan data panel tahun 2010 - 2015. Penelitian ini menggunakan uji Huasman dalam memilih model terbaik untuk metode General Last Square ( GLS ) dan hasil uji tersebut menunjukan bahwa Rendom Effects Model ( REM ) yang digunakan dalam menganalisis faktor Determinan yang mempengaruhi ketimpangan pendapatan di Kabupaten Maluku Tenggara Barat

Berdasarkan hasil estimasi tersebut bahwa variabel Jumlah Penduduk (X1) berpengaruh positife 0,041754 dan signifikan terhadap ketimpangan antar wilayah kabupaten kota. Sedangkan variabel Product Domestic Regional Brotu (X2) berpengaruh negetive dan signifikan ,dengan nilai -1.4805 dan variabel pengeluaran pemerintah (X3) berpengaruh negative dan signifikan terhadap ketimpangan antar wilayah.
\end{abstract}

\section{Kata kunci :Ketimpangan Pendapatan, Jumlah Penduduk, PDRB dan Pengeluaran Pemerintah}

\section{Pendahuluan}

Pada mulanya upaya pembangunan diidentifikasi dengan upaya peningkatan pendapatan per capita atau disebut strategi pertumbuhan ekonomi. Dengan ditingkatkannya pendapatan per kapita, diharapkan mampu memecahkan permasalahaan pengangguran, kemiskinan dan ketimpangan ditribusi pendapatan 
melaluitrickle down effect ( Kuncoro, 2010: 4). Pada awal tahun 1960-an, sebagian besar Negara Sedang Berkembang ( NSB) yang mengalami tingkat pertumbuhan tinggi menyadari bahwa pertumbuhan ekonomi semacam itu hanya memberikan sedikit manfaat dalam memecahkan masalah kemiskinan serta distribusi pendapatan (Arsyad, 2010: 280 ) permasalahaan pembangunan saat ini terutama di NSB bukan hanya berorientasi pada pertumbuhan, tetapi juga pada pemerataan distribusi

Tingkat lajur pertumbuhan ekonomi antar kabupaten di propinsi Maluku didukung oleh sector - sector usaha yang berkembang di daerah. Tingkat dan laju pertumbuhan ekonomi tersebut tidak terlepas dari perkembangan kinerja dan struktur perekonomian. Memang bahwa sector - sector ekonomi yang mempunyai peranan besar dalam perekonomian di antar kabupaten yang berada pada propinsi Maluku dari tahun ketahun.

Berikut ini dapat ditampilkan data perkembangan PDRB Kabupaten Maluku Tenggara Barat dari tahun 2010 - 2015 sebagai berikut
Tabel 1.1

Data Jumlah Jiwa, PDRB dan Pengeluaran Pemerintah Pada Kab. MTB, MARLA, KEPULAUAN ARU, MBD dan Kota Tual

Propinsi Maluku

\begin{tabular}{|c|c|l|c|l|}
\hline Kabupaten & Tahun & $\begin{array}{l}\text { Jumlah } \\
\text { Penduduk }\end{array}$ & PDRB & $\begin{array}{l}\text { Pengeluar } \\
\text { an } \\
\text { Pemerint } \\
\text { ah }\end{array}$ \\
\hline \multirow{4}{*}{ MTB } & 2010 & 105804 & 9.267643567 & 511847146 \\
\cline { 2 - 5 } & 2011 & 106768 & 9.84134441 & 582478491 \\
\cline { 2 - 5 } & 2013 & 107827 & 10.45590186 & 692288371 \\
\cline { 2 - 5 } & 2014 & 108665 & 10.90957199 & 945532470 \\
\cline { 2 - 6 } & 2015 & 109589 & 11.46146611 & $\begin{array}{l}1048094 \\
847\end{array}$ \\
\hline
\end{tabular}

Dari Tabel 1.1 dapat dilihat bahwa dapat dilihat bahwa adan kenaikan jumlah penduduk, PDRB dan Pengeluaran Pemerintah dari tahun 2010 - 2015 di Kabupaten Maluku Tenggara Barat memiliki Jumlah penduduk yang tertinggi pada dua tahun terakhir yaitu tahun 2014 - 2015 dengan jumlah 108,665 dan 109,598 Jiwa, sedangkan kalau dilihat dari Pertumbuhan Kabupaten Maluku Tenggara Barat dengan Jumlah PDRB sebesar 10,909,571.99 dan 11,461,466.11 di tahun 2014 dan 2015. Kalua didilihat pada pengeluaran pemerintah antara Kabupaten Maluku Tenggara Barat pada dua tahun terakhir yaitu kabupaten Maluku Tenggara Barat dengan data pengeluaran Pemerinta sebesar 945532470 dan 1048 094 847. Perbedaan data tersebut bukan 
hanya terjadi pada dua Kabupaten ini saja, melaikan terjadi pada Kabupaten -

\section{TINJAUAN PUSTAKA}

\section{Teori Pertumbuhan Ekonomi}

Istilah pertumbuhan ekonomi biasanya dikaitkan dengan perkembangan ekonomi di Negara - Negara berkembang. Sebagai ahli ekonomi mengartikan istilah ini sebagai berikut : economic development is growth plus change, yaitu pembangunan ekonomi adalah pertumbuhan ekonomi yang diikuti perubahan -perubahan dalam struktur dan corak kegiatan ekonomi. Dengan kata lain dalam mengartikan istilah pembagunan ekonomi, ahli ekonomi bukan saja tertarik kepada masalah perkembangan pendapatan nasional riil, tetepi juga kepada moderenisasi kegiatan ekonomi misalnya usaha merombak sector pertanian yang tradisional, masalah mempercepat pertubuhan ekonomi dan masalah pemerataan pendapatan ( Sukirno, 2006: 415 ).

\section{Teori Populasi Penduduk}

Ada pengaruh positif pertumbuhan penduduk terhadap pertumbuhan ekonomi
Kabupaten lainnya, ini dapat dilihat pada Tabel diatas.

dimana kondisi dan kemajuan penduduk sangat erat terkait dengan tumbuh dan berkembangan usaha ekonomi. Penduduk disatu pihak dapat menjadi pelaku atau sumber daya bagi faktor produksi, pada sisi lain dapat menjadi sasaran atau konsumen bagi produk yang dihasilkan. Kondisi - kondisi kependudukan, data informasi kependudukan akan sangat berguna dalam memperhitungkan berapa banyak tenaga kerja yang akan terserap serta kualifikasi tertentu yang dibutuhkan dan jenis - jenis teknologi yang akan dipergunakan untuk memproduksi barang dan jasa.

Dipihak lain pengetahuan tentang struktur penduduk dan kondisi social ekonomi pada wilaya tertentu, akan sangat bermanfaat dalam perhitungan beberapa penduduk yang dapat memanfaatkan peluang dan hasil pembangunan atau seberrapa luas pangsa pasarbagi suatu produk usaha tertentu (Todaro,2003 ).

Di era globalisasi dan perdagangan bebas, besarnya jumlah penduduk dan kekuatan 
ekonomi masyarakat menjadi potensi sekaligus sasaran pembangunan sosial ekonomi, baik untuk skala nasional baikpun internasional. Berdasarkan hal ini pembangunan sumber daya manusia perlu terus diitingkatkan agar kualitas penduduk sebagai pelaku ekonomi dapat meningkat sesuai dengan permintaan dan kebutuhan zaman yang terur berkembang.

Adam Smith ( 1729-1790) merupahkan toko utama dari aliran ekonomi yang kemudian dikenal sebagai aliran klasik. Dalam hal ini teori klasik Adam Smith juga melihat bahwa alokasi sumber daya manusia yang efektif adalah pemula pertumbuhan ekonomi. Setelah ekonomi tumbuh akomulasi modal ( fisik ) baru muali dibutuhkan untuk menjaga agar ekonomi tumbuh. Dengan kata lain alokasi sumber daya manusia yang efektif merupahkan syarat perlu bagi pertumbuhan ekonomi.

Menurut Mulaydi (2003), teori klasik menganggap bahwa manusialah sebbagai faktor produksi utama yang menentu kemakmuran bangsa - bangsa. Alasannya alam ( tanah ) tidak ada arti kalau tidak ada sumber daya manusia yang pandai mengelolah sehingga bermanfaat bagi kehidupan. Dalam hal ini teori klasik dari
Adam Smith (1729-1790) juga mlihat bahwa alokasi sumber daya manusia yang efektif adalah pemulaan pertumbuhan ekonomi. Setelah ekonomi bertumbuh, akumulasi modal (fisik) baru mulai dibutuhkan untuk menjaga agar ekonomi tumbuh. Dengan kata lain alokasi sumber daya manusia yang efektif merupahkan syarat perlu bagi pertumbuhan ekonomi.

Sesudah Adam Smith Thomas Robert Malthus ( 1766-1834) dianggap sebagai pemikir klasik yang sangat berjasa dalam pembangunan pemikiran - pemikiran ekonomi. Buku Malthus yang dikenal paling luas adalah Principles of Populaltion. Menurut Mulyadi (2003), dari buku tersebut akan dilihat bahwa meskipun Malthus termasuk salah seorang pengikut Adam Smith, tidak semua pemikiran sejalan dengan Smith. Disitu disatu pihak Smith optimis bahwa kesejateraan umat manusia akan selalu meningkat sebagai dampak positif dari pembagaiannk kerja dan spesialisasi. Sebaliknya Malthus justru pesimis tentang masa depan umat manusia kenyataan bahwa tanah sebagai salah satu faktor produksi utama tetap jumlahnya. Dalam banyak hal justru luas tanah bagi pertanian berkurang karena sebagian digunakan untuk membangun perumahan, 
pabrik-pabrik dan bangunan lainnya serta pembuuatan jalan. Memnurut Malthus manusia berkembang jauh lebih cepat dibandikan dengan prooduksi hasil pertanian untuk memenuhi kebutuhan manusia. Malthus tidak percaya bahwa teknologi mampu berkembang lebih cepat daripada pertumbuhan manusia. Sehingga perlu dilakukan pembatasan dalam jumlah penduduk. Pembatasan ini disebut Malthus sebagai pembatasan moral.

Kaum klasik percaya bahwa perekonomian yang didasarkan pada kekuatan mekanisme pasar akan selalu menuju keseimbangan (equilibrium). Dalam posisi keseimbangan semua sumber daya termasuk, tenaga kerja, akan digunakan secara penuh. Dengan demikian bahwa sistem yang didasarkan pada bahwa tidak ada pengangguran. Kalau tidak ada yang bekerja, dari pada tidak memperoleh pendapatan sama sekali, maka mereka bersedia bekerja dengan tingkat upah yang lebih rendah. Kesediaan bekerja dengan memperoleh tingkat upah yang lebih redah ini akan menarik perusahaan untuk lebih mempekerjakan mereka lebih banyak. Kriteria Jhon Maynard Keynes (188831946) terhadap system klasik sala satunya adalah tentang pendapatan yang mengatakan bahwa tidak ada mekanisme penyesuaian otomatis yang menjamin bahwa perekonomian akan mencapai keseimbangan pada tingkat penggunaan kerja penuh.

Teori Harrod-Domar dikenal sebagai teori pertumbuhan. Menurut teori ini dalam Mulyadi (2003), investasi tidak hanya menciptakan permintaan, tetapi juga memperbesar kapasitas produksi hanya dapat meningkatkan bila sumber daya lain ( modal fisik ) membesar. Di samping itu dalam model pertumbuhan, jumlah penduduk pyang besar tidak mengurangi perdapatan per kapita asalkan modal fisiknya meningkat. Model yang sama juga dikemukankan oleh model Solow dimana dalam model ini dipakai suatu fungsi produksi Cobb-Douglas. Angkatan kerja diasumsi tumbuh secara geometris dan full employment selalu tercapai. Tetapi, dalam model ini pekerja sudah memperluaskan secara jelas sebagai salah satu faktor produksi, dan buka sekedar pembagi. Dalam model ini juga dilihat subtitusi antara modal fisik dan pekerja.

\section{Produk Domestik Regional Bruto (PDRB}


PDRB merupakan jumlah nilai tambah yang dihasilkan oleh seluruh unit usaha dalam suatu wilayah tertentu, atau merupakan jumlah nilai barang dan jasa akhir yang dihasilkan oleh seluruh unit ekonomi. Untuk menghitung angka PDRB ada tiga pendekatan yang dapat digunakan, yaitu:

1. Pendekatan Produksi, PDRB adalah jumlah nilai barang dan jasa akhir yang dihasilkan oleh berbagai unit produksi di wilayah suatu daerah dalam jangka waktu tertentu (biasanya satu tahun).

2. Pendekatan Pengeluaran, PDRB adalah semua komponen permintaan akhir seperti: (a) pengeluaran konsumsi rumahtangga dan lembaga nirlaba, (b) konsumsi pemerintah, (c) pembentukan modal tetap domestik bruto, (d) perubahan stok, dan (e) ekspor neto, dalam jangka waktu tertentu (biasanya satu tahun).

3. Pendekatan Pendapatan, PDRB merupakan jumlah balas jasa yang diterima oleh faktor-faktor produksi di suatu daerah dalam jangka waktu tertentu. PDRB ADHB digunakan untuk melihat pergeseran dan struktur ekonomi.
PDRB ADHB menunjukkan pendapatan yang memungkinkan dapat dinikmati oleh penduduk suatu daerah serta menggambarkan nilai tambah barang dan jasa yang dihitung menggunakan harga pada setiap tahun.

PDRB ADHK digunakan untuk mengetahui pertumbuhan ekonomi dari tahun ke tahun, untuk menunjukkan laju pertumbuhan ekonomi secara keseluruhan/setiap sektor dari tahun ke tahun. Data PDRB ADHK lebih menggambarkan perkembangan produksi riil barang dan jasa yang dihasilkan oleh kegiatan ekonomi daerah tersebut.

PDRB ADHB menurut sektor menunjukkan peranan sektor ekonomi dalam suatu daerah,sektor-sektor yang mempunyai peranan besar menunjukkanbasis perekonomian suatu daerah. Dengan demikian PDRB secara agregatif menunjukkan kemampuan suatu daerah dalam menghasilkan pendapat.

\section{Pengeluaran Pemerintah}

Rudy Badrudin menjelaskan bahwa pengeluaran konsumsi pemerinta mencakup pengeluaran untuk belanja pegawai, penyusutan barang modal, dan belanj barang (termasuk belanja 
perjalanan, pemeliharaan, dan pertumbuhan ekonomi secara teori pengeluaran lain yan bersifat rutin) diterangkan dalam Keynesian Cross dikurangi penerimaan dari produksi barang dan jasa yang dihasilkan Pengeluaran konsumsi pemerintah tersebut meliputi pemerintah pusat dan pemerinta daerah.

$\begin{array}{lrrr}\text { Pada dasarnya setiap pengeluaran } \\ \text { negara dilakukan atas landasan } & \text { prinsi } \\ \text { optimalisasi pemanfaatan dana } & \text { untuk } \\ \text { mencapai } & \text { sasaran-sasaran } & \text { yang } \\ \text { ditetapkan pengeluaran } & \text { pemerintah } \\ \text { harus mampu } & \text { mencapai } & \text { beberapa } \\ \text { sasaran, } & \text { seperti } & \text { peningkatan }\end{array}$
produktivitas kerja aparatur pemerintah, perluasan jangkauan da peningkatan kualitas pelayanan kepada masyarakat, pembinaan dan pengawasa pelaksanaan pembangunan serta terpeliharanya berbagai aset negara dan hasil-hasil pembangunan.

Pengeluaran pemerintah mencerminkan kebijakan pemerintah. Apabil pemerintah telah menetapkan suatu kebijakan untuk membeli barang dan jasa pengeluaran pemerintah mencerminkan biaya yang harus dikeluarkan oleh pemerintah untuk melaksanakan kebijakan tersebut (Mangkoesoebroto, 1993; 169) Hubungan antara pengeluaran pemerintah dan (Mankiw, 2003; 263).

Pemerintah tidak cukup hanya meraih tujuan akhir dari setiap kebijakan pengeluarannya, tetapi juga harus memperhitungkan sasaran antara yang akan menikmati atau terkena kebijakan tersebut. Memperbesar pengeluaran dengan tujuan semata-mata untuk meningkatkan pendapatan nasional atau memperluas kesempatan kerja adalah tidak memadai melainkan harus memperhitungkan siapa (masyarakat lapisan mana) yang bekerja atau meningkat pendapatannya. Pemerintah pun perlu menghindari agar peningkatan perannya dalam perekonomian justru melemahkan.

Hubungan perkembangan pengeluaran pemerintah dengan tahap-tahap pembangunan ekonomi yang dibedakan antara tahap awal, tahap menengah, dan tahap lanjut. Pada tahap awal perkembangan ekonomi, persentase investasi pemerintah terhadap total investasi besar sebab pada tahap ini pemerintah harus menyediakan prasarana seperti pendidikan, kesehatan, prasarana 
transportasi dan sebagainya

(Mangkoesoebroto, 2002, hal 170).

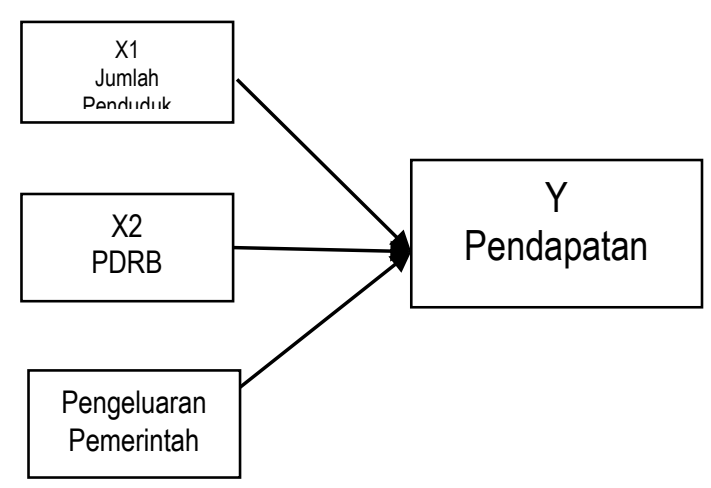

Metode penelitian

\section{Model Analisis Ekonometrikra}

Model ini untuk menganalisis factor yang menyebab terjadinya ketimpangan pendapatan, maka diuji regresi anatar indeks Williamson dengan jumlah penduduk, PDRB, Pengeluaran pemerintah.

$$
\mathrm{Y}=\mathrm{f}\left(\mathrm{X}_{1}, \mathrm{X}_{2}, \mathrm{X}_{3}\right) \text { atau : }
$$

Dalam menganalisis data pada penelitia ini penulis menggunakan data panel. Dimana data panel merupahkan data campuran cross selection time series ( Wahyu A. Pratomo, 2007 ). Penggunaan data panel didasarkan pada kenyataan bahwa data yang tersedia, seriesnya tidak mencukupi untuk dilakukan. Model yang digunakan adalah :

$Y_{i t}=\alpha+\beta_{1} X_{1 i t}+\beta_{2} X_{2 i t}+\beta_{3} X_{3 i t}+\mu$

Dimana :

$$
\begin{aligned}
& Y_{\text {it }} \text { : Pendapatan Antar } \\
& \text { kabupaten kota ke-i tahun } \\
& \text { 2012-2016 } \\
& \alpha \text { : Intercep/Dugaan } \\
& \text { parameter } \\
& \beta_{1} \text { : Koefisien jumlah } \\
& \text { penduduk pada } 5 \text { (lima) } \\
& \text { Tahun 2012-2016 } \\
& \beta_{2} \text { : Koefisien Product } \\
& \text { Domestic Regional Broto } \\
& \text { (PDRB) pada } 5 \text { (lima) } \\
& \text { Tahun 2012-2016 } \\
& \beta_{3} \text { : Koefisien pengeluaran }
\end{aligned}
$$

\section{Hasil dan Pembahasan}

Model ini untuk menganalisis adanya Pengaruh ketimpangan pendapatan, maka diuji regresi antara indeks Williamson dengan jumlah penduduk, PDRB, 
Pengeluaran pemerintah, yang telah dituangkan pada rumusan masalah bahwa Apakah ada pengaruh Jumlah Penduduk, PDRB, Pengeluaran Pemerintah terhadap Ketimpangan antar Wilayah. Dan juga untuk digunakan untuk membuktikan hipotesis sebagai jawaban sementara atas rumusan masalah bahwa diduga ada Pengaruh Jumlah Penduduk, PDRB, Pengeluaran Pemerintah secara signifikan Terhadap Ketimpangan Wilayah, Untuk membuktikan hipotesis tersebut, digunakan alat analisis regresi linear berganda. Dengan diperoleh persamaan regresi estimasi sebagai berikut (output lengkap lihat lampiran):

$$
\begin{aligned}
& \mathbf{Y}=1,429463+0.041754 \mathrm{X}_{1}+- \\
& 1.48 \mathrm{E}-05 \mathrm{X}_{2}+-0.000340 \mathrm{X}_{3}+\mu \\
& t \\
& F=4,600477 \\
& R^{2}=0,346757
\end{aligned}
$$

\section{Keterangan:}

$$
\begin{aligned}
& Y=\text { Ketimpangan Antar } \\
& \quad \text { Wilayah } \\
& X 1=\text { Jumlah Penduduk } \\
& X 2=\text { Product Domestic Regional } \\
& \quad \text { Bruto } \\
& X 3=\text { Pengeluaran Pemerintah }
\end{aligned}
$$

\section{Tabel 4.7}

Hasil Analisis Regresi Linier Berganda

$$
Y_{i t}=\alpha+\beta_{1} X_{1 i t}+\beta_{2} X_{2 i t}+\beta_{3} X_{3 i t}+\mu
$$

\begin{tabular}{|l|c|c|c|}
\hline \multicolumn{1}{|c|}{$\begin{array}{l}\text { Variabel } \\
\text { Bebas }\end{array}$} & $\begin{array}{c}\text { Koefisien } \\
\text { Regresi }\left(\mathrm{b}_{\mathrm{i}}\right)\end{array}$ & $\begin{array}{c}\text { Statistik } \\
\mathrm{T}\end{array}$ & $\mathrm{P}$ \\
& & & \\
\hline Konstanta & 1,429463 & 0,500400 & 0,6210 \\
\hline Jumlah Penduduk $\left(\mathrm{X}_{1}\right)$ & 0.041754 & 3,226431 & 0,0456 \\
\hline PDRB $\left(\mathrm{X}_{2}\right)$ & $-1.48 \mathrm{E}-05$ & $-3,216270$ & 0,4476 \\
\hline $\begin{array}{l}\text { Pengeluaran Pemerintah } \\
\left(\mathrm{X}_{3}\right)\end{array}$ & -0.000340 & $-2,415124$ & 0,4526 \\
\hline $\begin{array}{l}\text { Koefisien Determinasi } \mathrm{R}^{2}=0,346757 \\
\text { Statistik F }=4,600477 ; \mathrm{p}=0,010338\end{array}$ \\
Sumber: Data Panel (Diolah 2017) \\
\hline
\end{tabular}

Dilihat dari hasil regres tersebut maka interprestasinya sebagai berikut :

1. Jumlah penduduk pada empat kabupaten dan satu kota madya mempunyai pengaruh positif terhadap tingkat ketimpangan dengan koefisien sebesar 0.041754, artinya apabila jumlah penduduk pada $\underline{\underline{a}}$ naik, selgesar $1 \%$, cateris 3270 paribus maka tingkat ketimpangan antar kabupaten dan satu kota madya naik sebesar $0.041754 \%$. Artinya, jumlah penduduk memliki pengaruh yang cukup besar terhadap ketimpangan yang cukup tinggi antar kabupaten kota.

2. PDRB perkapita Kabupaten dan kota madya mempunyai pengaruh negatife terhadap tingkat ketimpangan wilyah dengan nilai koefisien sebesar -1.4805 yang artinya apabila PDRB perkapita di 
empat kabupaten dan satu kota madya naik sebesar $1 \%$, ceteris paribus maka ketimpangan antar wilayah mengalami penurunan sebesar $-1.4805 \%$, ssesuai dengan studi Rapoparot (1999) yang menyebut bahwa pertumbuhan ekonomi local berpengaruh negatife terhadap pesar keuangan pemerintah. Sehinggah dapat disimpulkan bahwa tingkat PDRB perkapita didasarkan pada pertumbuhan ekonomi lokal, hal ini juga membuat PDRB berpengaruh negative terhadap Ketimpangan antar wiyalah

\section{Pengeluaran}

pemerintah mempunyai pengaruh negative terhadap tingkat ketimpangan wilayah di empat kabupaten dan satu kota madya dengan nilai koefisiennya sebesar -0.000340 yang artinya apabila pengeluaran pemerintah naik sebesar $1 \%$, ceteris paribus maka kketimpangan antar kabupaten dan satu kota madya mengalami kenaikan sebesar $0.000340 \%$.

\section{Kesimpulan}

Pengaruh Jumlah Penduduk Terhadap Ketimpangan Pendapatan
Diperoleh koefisien regresi variable jumlah penduduk yang dinotasikan dengan ( $\beta_{1}$ ) sebesar 1.36. Nilai koefisien variable Jumlah Penduduk ( $\beta_{1}$ ) tersebut ternyata berpengaruh signifikan secara statistic pada tingkat signifikansi $\alpha$ ( alfa ) $=5 \%$ atau tingkat kepercayaan 95\%. Hal ini juga dapat dilihat dengan membandingkan antara nilai propabilitas ( $p$-value) dengan tingkat signifikansi dimana variable jumlah penduduk memiliki propabalitas sebesar $0.0057>(\alpha=5 \%)$.

Nilai koefisiean Jumlah penduduk (X1) sebesar 1.36 menunjukan bahwa ada hubungan positif antara jumlah penduduk dengan Pendapatan wilayah pada lima di Kabupaten Maluku Tenggara Barat, yang artinya semakin tinggi jumlah penduduk maka semakin tinggi tingkat ketimpangan. Nilai koefisien jumlah penduduk (X1) sebsar 1,36 memiliki arti jika jumlah penduduk meningkat sebesar 1 persen makan Pendapatan di Kabupaten Maluku Tenggara Barat akan meningkat sebesar 1,36 persen.

\section{Pengaruh PDRB Terhadap}

\section{Ketimpangan Pendapatan}

Diperoleh koefisien regresi variable Product Domestic Bruto (PDRB) yang 
dinotasikan dengan $\left(\beta_{2}\right)$ sebesar $-3,14$. Nilai koefisien variable PDRB ( $\left.\beta_{2}\right)$ tersebut ternyata berpengaruh negative dan tidak signifikan secara statistic pada tingkat signifikansi $\alpha($ alfa $)=5 \%$ atau tingkat kepercayaan 95\%. Hal ini juga dapat dilihat dengan membandingkan antara nilai propabilitas ( $p$-value) dengan tingkat signifikansi dimana variable PDRB memiliki propabalitas sebesar $0.027>$ $(\alpha=5 \%)$,

Nilai koefisiean PDRB (X2) sebesar -3,14 menunjukan bahwa ada hubungan neegatife antara jumlah PDRB dengan Pendapatan pada Kabupaten Maluku Tenggara Barat yang artinya semakin tinggi PDRB maka semakin besar juga tingkat pendapatan. Nilai koefisien PDRB (X2) sebsar -3,14 memiliki arti jika PDRB meningkat sebesar 1 persen maka pendapatan wilayah pada lima kabupatenN naik sebesar 3,14 persen.

\section{Pengaruh Pengeluaran Pemerintah}

Terhadap Ketimpangan Pendapatan

koefisien regresi variable Pengeluaran Pemerintah yang dinotasikan dengan $\left(\beta_{3}\right)$ sebesar -2.84. Nilai koefisien variable Pengeluaran Pemerintah $\left(\beta_{3}\right)$ tersebut ternyata berpengaruh negative dan tidak signifikan secara statistic pada tingkat signifikansi $\alpha($ alfa $)=5 \%$ atau tingkat kepercayaan 95\%. Hal ini juga dapat dilihat dengan membandingkan antara nilai propabilitas ( $p$-value ) dengan tingkat signifikansi dimana variable jumlah penduduk memiliki propabalitas sebesar $0.527>(\alpha=5 \%)$.

Nilai koefisiean Pengeluaran pemerintah (X3) sebesar -2,86 menunjukan bahwa ada hubungan neegatife antara pengeluaran pemerintah dengan ketimpangan pendapatan pada, yang artinya semakin tinggi Pengeluaran pemerintah maka semakin kecil tingkat ketimpangan pendaptan. Nilai koefisien Penegeluaran pemerintah (X3) sebsar -2,86 memiliki arti jika penegeluaran pemerintah meningkat sebesar 1 persen maka ketimpangan pendapatan pada kabupaten akan turun sebesar 2,86 persen.

\section{DAFTAR PUSTAKA}

Astute, Esther Sri, Desentralisali Fiskal dan ketimpangan dearah di Indonesia, makro Ekonomi, Usahawan No. 022 Tahun 2007

Anisa darma Yanti, Faktor - factor yang mempengaruhi ketimpangan pendapatan Antar Kabupaten kota di Propinsi Jawa Timur, Tahun 2012 
Ari Muliana, 2015, Pengaruh ketimpangan pembangunan antar wilayah terhadap kemiskinan di Indonesia

Badan Pusat Satistik Propinsi Maluku, Maluku Dalam angka, 2015 - 2016

Deliarnov, 1995, Perkembangan Pemiiran Ekonomi, penerbit PT RajaGrafindo, Jakarta.

Hidaryati, R.A. 2008 Analisis Ketimpangan Ekonomi antar Kecamatan di Kabupaten gresik. Jurnal Logos Vol 6

Jhingan, ML. 2001. Ekonomi Pembangunan dan Perencanaan. Jakarta:PT. Raja Grifindo Persada

Krisnantiya, 2014 Faktor-faktor yang mempengaruhi ketimpangan antar wilayah di privinsi Jawa Timur dan Daerah Istimewa Jogjakarta.

Kuncoro Mudrajad, 2004, Otonomi dan Pemabangunan Daerah: Refomasi, Perencanaan, Strategi, dan Peluang, Penerbit, Erlangga, Jakarta.

Kuncoro Mudrajat, Ekonomi Development, Analisis Jurnal Vol 52 May, 2010

Lukman harun, Gozila Maski, 2011, Pengaruh pengeluaran pemerintah daerah dan pertumbuhan ekonomi terhadap ketimpangan wilayah di propinsi Jawa Timur

Muhammad Arsyad, 2010, Pengeruh Pertumbuhan Ekonomi, Indeks Pemebangunan Manusia dan Belanja Langsung Terhadap Kemiskinan
Mangkoesoebroto, Guritno,1993, Ekonomi Publik, Edisi-iii, BPFE, Yogyakarta

Marzuki, 2015, Metodologi Riset Ekonisia, Yogyakarta

Mulyadi, 2003 pengaruh Pertumbuhan Ekonomi, Upah Minimum, dan investasi terhadap jumlah Pengangguran di Kabupaten Greesik

Sadono, Sukirno, 1994, Pengantar Teori Ekonomi, Edisi Kedua, Rajawali Perss. Jakarta.

Sadono, Sukirno, 1999, Makroekonomi Modern, Perkembangan Pemikiran dari Klasik hingga Keynesian Baru, Penerbit PT. RajaGrafindo Persada, Jakarta.

Sugiyona. 2009. Metode Penelitian Kuantitatif, Kualitatif dan R\&D. Bandung

Sutarno, Pertumbuhan Ekonomi dan ketimpangan Antara Kecamatan di Kabupaten Banyumas ( 2003 )

Sjafrizal, 2008. Pertumbuhan Ekonomi dan Ketimpangan Regional Wilayah Indonesia Bagian Barat, Prisma, 3 Maret

Siti Parhal, Kontribusi desentralisasi Filkal Terhadap Pertumbuhan Ekonomi di Indonesia, Tahun 2014

Tasri,Evi susanti, kesenjangan Pembangunan Ekonomi Antar Derah Tinggkat II di propinsi Sumatra Barat Tahun 1985 - 2003

Tadoro dan Smith, 2006, Analisis Pengelolahan Keuangan Daerah dan dampak pada Pembangunan Ekonomi di Propivinsi Jawa Timur 